\title{
Freedom, the state, and war: Hegel's challenge to world peace
}

\author{
Shinkyu Lee ${ }^{1}$
}

\begin{abstract}
Several conflict theorists have appropriated Hegel's 'struggle for recognition' to highlight the healthy dimensions of conflict and to explore ways of reaching reconciliation through mutual recognition. In so doing, some scholars attend to the interpersonal dimension of reconciliation, while others focus on the interstate dimension of reconciliation. This paper argues that both approaches miss important Hegelian insights into the modern state. Hegel understands that freedom must be situated and bounded in order to take a concrete form. He believes that concrete freedom and domestic reconciliation create an atmosphere that can pressure the state to be more confrontational with other states by attaining a stronger individuality. Thus, the common concern about freedom among Hegelian states remains a 'thin' version of communication, vulnerable to such factors as national honor or recognition status. Hegel's challenge urges peace-inspired scholars to explore ways of achieving concrete freedom and domestic reconciliation while simultaneously relieving interstate conflict.
\end{abstract}

Keywords Hegel - Struggle for recognition - Reconciliation - Levels of politics · World state . Wendt

\section{Introduction}

Recently, there has been a growing interest in the positive role of conflict for creating constructive change processes. Instead of considering conflict as a force that is diametrically opposed to peace, several conflict scholars have highlighted the relevance of analyzing its context and dynamics in peace processes (e.g. Lederach

Shinkyu Lee

slee25@nd.edu

1 Kroc Institute for International Peace Studies, University of Notre Dame, 100 Hesburgh Center for International Studies, Notre Dame, IN 46556-5677, USA 
1998, 2003; Richmond 2011). Investigating the constructive opportunities that conflict can make, they argue, helps to reveal the deeper patterns of human relationship and causes of violence. ${ }^{1}$ Moreover, some theorists find this approach politically adequate, because it avoids excessive reliance on absolute moral values grounded in an idealistic world while at the same time serving to actively engage in the politics of this world (Geuss 2010, pp. 31-41; Williams 2005; Mouffe 1993).

Taken in this theoretical orientation, Hegel's thought seems to be both insightful and problematic. On the one hand, Hegel scholars highlight his notion of the 'struggle for recognition' as illuminating the healthy dimensions of conflict and uncovering paths to reconciliation through mutual recognition (Taylor 1994; Honneth 1996; Lindemann and Ringmar 2012). If peace and reconciliation are best sought through the strenuous process of conflict, and not through its absence, Hegel's thought can provide a solid foundation for this line of reasoning. On the other hand, Hegel's statements about the modern state and war appear to be highly problematic. The recurrent charge is that the Hegelian state could swallow up individuality and facilitate the rise of a totalitarian regime (Popper 1996, p. 31; Cassirer 1946, pp. 248-276; Adorno 1973, pp. 349-350). In a similar vein, some scholars in the field of international relations (IR) contend that Hegel's Philosophy of Right mounts a strong defense of state sovereignty and thus supports the assumptions of realist IR theory (Brook 2012a, pp. 134-143).

Commentators have made numerous attempts to assuage such a difficult feature of Hegel's thought (e.g. Avineri 1996; Jaeger 2002, p. 508; Brown 2002, pp. 50-51). Among recent studies, there are two ways of dealing with Hegel's state theory. ${ }^{2}$ One focuses on the master-and-slave narrative of recognition in Hegel's Phenomenology of Spirit (1977, pp. 110-119). On this basis, it distinguishes a Hegelian theory of global justice from Hegel's theory of international politics (Brook 2012b; Geiger 2007). The latter, mostly contained in The Philosophy of Right, is too outdated to be accepted in the era of globalization. The struggles for recognition among local actors are relevant to consider, but not those of state actors. Thus, this rendition of Hegel's thought is aligned with some of the sociological literatures that treat the nation-state as an obstacle to promoting social movements of global justice (Kaldor 2013; Smith 2007). The other approach is found among several IR scholars inspired by social constructivism. Notably, Alexander Wendt argues that the culture of international politics will evolve to the point of necessitating a world state. Behind Wendt's claim is the structuralist assumption that the state is not only real but it also has a personhood-an independent character not reducible to its constituents (Wendt 2004). This is why the Hegelian struggle for recognition 'operates on two levels simultaneously, between individuals and

\footnotetext{
1 This idea resonates with the line of research on 'positive peace' that Galtung (1969) famously conceived as more than the absence of violence and that of 'structural violence' that attests to the significance of investigating the root causes of violence (Weigert 2008).

2 The article does not deal with the approach to radically depart from Hegelian understanding of recognition struggle and identity formation. Some scholars (Bartelson 2013, pp. 125-127; Lebow 2008) identify the ontological contrast between the Self and the Other in the Hegelian dialectic and claim that such a distinction is not necessary for identity formation. Though not ignorant of such a radical critique, this paper seeks to explore what Hegel's statist model can provide for modern politics.
} 
between groups' (Wendt 2003, p. 516). If the problem is that the Hegelian process of mutual recognition does not operate beyond state boundaries, this concern is overcome in Wendt's structuralist appropriation of Hegel's ideas. Just as individual struggles for recognition are reconciled in the state, struggles between states are reconciled within a supranational body like the world state.

Whereas the first approach accentuates the individual's capacity to influence politics by forming social movements, the second purports to capture the effects of the changing structure of international relations. In other words, one emphasizes the interpersonal dimension of reconciliation, while the other focuses on the interstate dimension of reconciliation. Despite their difference, both approaches converge on the argument that the competitive nature of interstate relations is a problem to overcome. Thus, one theoretical strategy is to argue that although it is crucial to know the actual context of recognition struggles occurring at the individual (and group) level, this task can be fulfilled without taking into consideration state institutions and interstate competition. The other one is to claim that states-which have the same psychological propensities as individuals - must facilitate the rise of the world state, because states are gradually cognizant of, and restrained by, the much higher cost of their competition due to the technological development of modern weaponry.

This paper argues that although these approaches are founded on Hegelian principles, they miss important Hegelian insights. Hegel understands that freedom must be situated and bounded in order to take a concrete form, and that concrete freedom can be effectively realized in the modern rational state. He also believes that concrete freedom and domestic reconciliation create an atmosphere that can pressure the state to be more confrontational with other states by attaining a stronger individuality. For the creator of the recognition theory, then, reconciliation through mutual recognition does not point to a complete homogenization of humanity across all states. Rather, the common concern about freedom among Hegelian states remains a 'thin' version of communication, vulnerable to such factors as national honor or recognition status.

The article begins by articulating Hegel's accounts of freedom. After explaining the significance that Hegel attributes to the state in achieving concrete freedom, the paper retrieves the contrasting relationship between domestic reconciliation and interstate conflict from Hegel's state model. In so doing, it makes critical remarks on the recent appropriation of Hegel's idea of recognition for cosmopolitanism. This study concludes with the suggestion that Hegel's thought urges peace-inspired scholars to explore ways of achieving concrete freedom and domestic reconciliation while simultaneously relieving interstate conflict.

\section{Freedom and the state}

This section articulates how and why Hegel appreciates the modern state. Its basic argument is that for Hegel, our pursuits of freedom, as well as struggles for recognition, should occur in an institutionally articulated space, that is, the rational 
(or constitutional) state. In reaching this point, we should, at least briefly, discuss Hegel's special terms like rationality and freedom.

Readers of The Philosophy of Right can readily recognize Hegel's positive view of the modern state. Needless to say, however, the world is full of historical examples of the state's wrongdoings. Why, then, does Hegel so valorize the idea of the state? In a sense, The Philosophy of Right was an attempt to articulate the rational principles found in the modern state, that is, things related to how individual claims to rights and welfare are mediated through the state's well-structured, wellfunctioning set of institutions. In this regard, if a particular state is identified as a despotic regime depriving the people of their basic rights, that situation only reveals how the state lacks what it is supposed to possess.

Yet, by elevating the significance of the rational principles of the modern state, Hegel does not mean to confirm some kind of pure abstract thinking. As his famous dictum - 'What is rational is actual; and what is actual is rational.'-suggests, Hegel (1991, p. 20) believes that the task of philosophy is not to formulate some principles that are detached from the realities and necessities of a social world. Hence, if a state is recognized as despotic, the measure of this identification should not be a predetermined ethical ethos but the rational principles already embodied in the modern state and its social institutions. This is closely related to his view on reality: whereas mere existence (or what is simply seen in reality) does not fully reflect the rational, it is not entirely devoid of rationality either. ${ }^{3}$ Hegel characterizes his distinctive method:

As far as nature is concerned, it is readily admitted that philosophy must recognize it as it is, that the philosopher's stone lies hidden somewhere, but within nature itself, that nature is rational within itself, and that it is this actual reason present within it which knowledge must investigate and grasp conceptually_not the shapes and contingencies which are visible on the surface, but nature's eternal harmony, conceived, however, as the law and essence immanent within it. (Hegel 1991, p. 12)

This passage points out the need to comprehend 'the content which is already rational' in the actual world (Hegel 1991, p. 11). In this methodological orientation, Hegel's arguments about the state deal with the rational principles that are found in the structure of the modern state. Indeed, Hegel is convinced that rationality is already embodied in the modern state to a considerable extent-especially when compared with that of ancient society. On this ground, he reaches the conclusion that the state as such is worth retaining, even when the sovereign system of states may put them in conflict and create the possibility of war.

We will soon turn to the case of war in Hegel's thought. Prior to that, we need to specify what Hegel means by the rationality embodied in the state. This implies that when people form reasons in taking action at the concrete level, their reasons are already embodied in public institutions. At the same time, the embodied rationality highlights the crucial function of the state in achieving the good, that is, the role of

\footnotetext{
${ }^{3}$ This makes Hegel's thought different from Kantian dualism. On the attempt to present Hegel as resisting typical incompatibilist libertarianism, see Pippin (2008).
} 
the state in providing concrete terms through which citizens (ought to) understand the obligations that derive from their moral concerns. This further requires us to articulate what Hegel means by the good. Hegel (1991, p. 157) defines the good as 'the Idea [considered] as the unity of the concept of the will and the particular will, in which abstract right, welfare, the subjectivity of knowing, and the contingency of external existence ... are superseded; but they are at the same time essentially contained and preserved within it.' Hegel's point here is that the good is the unity of two essential qualities of freedom: abstract right and welfare. In the sphere of abstract rights, individuals are bearers of rights, the latter that should not be violated. Welfare, by contrast, is comprised of the demands of particular ends that must be satisfied for the individual to see herself as free. As far as Hegel is concerned, these two principles of freedom ought to complement each other. Hegel mentions two problems on this score. One problem is that abstract right alone lacks the minimal moral disposition that is necessary to motivate juridical claims. On the other hand, the pursuit of the demands of welfare, if not properly informed of individual rights, can dissolve into a radical subjectivism. The good in Hegel's sense refers to the status of overcoming these possible defects and reconciling two initially separated principles of freedom (Franco 1999, p. 214; Shelton 2000, p. 392; Wallace 1999). Once their unity is achieved, Hegel (1991, p. 157) understands that 'welfare has no validity for itself as the existence of the individual and particular will, but only as universal welfare and essentially as universal in itself, i.e. in accordance with freedom.'

This then leads to another question: How does the unity of rights and welfare occur? Here the main concern is that there can be an indeterminable number of claims to rights and particular ends, and an enormous number of ways of combining them. With no limit, then, claims to rights and welfare and their proper reconciliation cannot be actualized. The modern constitutional state, Hegel claims, resolves this problem in that it provides the concrete setting for the unity of rights and welfare for all. In Hegel's view, individual claims are mediated within the constitution by the institutional articulation of the universal rights they have and the particular ends they pursue. Thus, the state is crucial for concrete freedom as the condition that enables the good to be realized. Hegel (1991, p. 285) makes this point clear by arguing: "[t]he determinations of the will of the individual acquire an objective existence through the state... The state is the sole precondition of the attainment of particular ends and welfare.'

But there can be at least two general concerns about Hegel's state model. One is whether this model imposes an excessive and illiberal degree of identification with the state on the citizens. While this is an important challenge, Hegel's thought is too complex to be dismissed as anti-liberal. For example, Hegel (1991, p. 282) considers the rational state as the one in which 'personal individuality and its particular interests should reach their full development and gain recognition of their right for itself (within the system of the family and of civil society).' Here, Hegel tries to assure us that the individuals in the modern state are not docile subjects who merely succumb to the authority of the state. Hegel (1991, p. 282) also makes it clear that the rational state actualizes freedom, "not in accordance with subjective caprice, but in accordance with the concept of the will, i.e. in accordance with its 
universality and divinity.' In Hegel's thinking, then, ruling over the people according to the arbitrary will of a despot does not match with the rational state. So, if a particular state is operated 'by that feeling which reserves the right to do as it pleases, [or] by that conscience which identifies right with subjective conviction,' Hegel would argue that that state is alienated from the constitution and 'imperfect' (Hegel 1991, p. 17; p. 282).

Secondly, there can be a question about whether the modern state has ever reached the point of serving the exalted function in ethical life that Hegel assigned it. Does the modern state provide for 'the transition of individual into communal life in the way Hegel's theory demands,' or do modern individuals really 'identify themselves rationally with their social roles' (Wood 1990, p. 259)? As will be detailed in the next section, Hegel acknowledges that the specific extent to which citizens are committed to, or alienated from, the state can be varied on a case-bycase basis. Overall, though, he insists that some comprehensive modes of thinking exist in the modern world and modern individuals are not completely alienated from the whole, that is, the rational state. ${ }^{4} \mathrm{He}$ adds that the reason why the political disposition to reconcile individual interests with those of the state is not easily identifiable is because it takes a habituated form. Hegel (1991, p. 289) specifies this idea by considering patriotism of modern citizens as the 'disposition which, in the normal conditions and circumstances of life, habitually knows that the community is the substantial basis and end.' This habitual confidence in the state makes modern citizens' patriotic disposition embedded in their ordinary lives. In the ethical moment of war, however, the subconscious patriotic mindset renders itself more visible. Hegel (1991, p. 361) argues that war serves as a crucial reminder of the importance of the rational state, revealing that the concrete way of actualizing freedom is not feasible without the state. By drawing attention to the warrior-like image of modern citizens who risk their lives in defense of their public space for concrete freedom, Hegel's thought on war challenges the claim that individuals in the modern world are completely disconnected and selfish. In his view, the cause of modern citizens' commitment to the rational state cannot be reduced to personal interest and honor. ${ }^{5}$ Instead, such a commitment derives from the fundamental concern about how to achieve freedom. Reconciling their particular interests with those of the state, modern individuals develop the conviction that their particular

\footnotetext{
${ }^{4}$ Shelton (2000, pp. 395-396) provides a helpful illustration of this point. He supposes that American automobile manufacturers lost competitiveness and encountered economic difficulty in foreign markets. Shelton speculates that as modern individuals, they should be informed that petitioning for the government's direct purchase of American automobiles can bring about adverse economic impact or the tax burden on fellow citizens. As such, some kind of holistic thinking, if habituated, restrains and affects their actions.

5 Hegel sees a fundamental difference between the state and civil society, and this explains why he thinks that personal interest is insufficient for generating citizens' devotion to the state. For Hegel, the state should be more than a place of taking care of 'the security of the life and property of individuals (Hegel, 1991, p. 324).' The Hegelian state does not ignore individual interests, but this cause fits more with civil society than the state. Secondly, as Smith (1983, p. 629) points out, Hegel questions if pursuing personal honor and excellence can be the real cause of generating the commitment of modern citizens to the state. In Hegel's view, a war driven by personal honor is more compatible with the image of the ancient warrior than that of its modern counterpart.
} 
ends and welfare cannot be actualized if the state is lost. In that regard, protecting their communal space for concrete freedom becomes the chief reason of modern warfare. ${ }^{6}$

\section{The state and war}

The preceding section explained why Hegel values the modern state. In his view, the state was essential for achieving concrete freedom. This section investigates how Hegel's state model affects his views on war (revolution and interstate war). In so doing, it makes the argument that the Hegelian state has two related features: domestic reconciliation and interstate conflict.

\section{Domestic reconciliation}

According to our discussion of Hegel's idea of the state in the previous section, it is not difficult to reach the conclusion that Hegel objects to revolution. Hegel claims that we, the modern, have found a concrete way of actualizing freedom, that is, the rational state where our individual claims are mediated by the institutional articulation of the rights we have and the ends we pursue. If everything is perfectly mediated and reconciled, then there will be no need to resort to civil war. So the case seems to be rather simple-Hegel dismisses revolution.

But Hegel is also aware that there is variation in the extent to which citizens are committed to, or alienated from, the state. In Hegel's writings, we identify at least two other cases than the fully rational state. For an analytical purpose, let us name them immature and dysfunctional states. First, the immature state refers to the condition that Hegel (1991, pp. 282-283) describes as '[i]mperfect states ... in which the Idea of the state is still invisible and where the particular determinations of this Idea have not reached free self-sufficiency.' A good case in point is the ancient states where 'the subjective end was entirely identical with the will of the state (Hegel 1991, p. 285).' Both in The Philosophy of History and The Philosophy of Right, Hegel argues that the modern state is different from the ancient state because the inner, subjective life is respected in the modern state. ${ }^{7}$ Thus, if a state completely lacks the modern function Hegel characterizes, that state has to be immature-not fully grown to the level of the modern rational state. In such a case, Hegel's position on revolution can be affirmative; that is, Hegel would not object revolution, while conceding the possibility that the evolving rational consciousness of the people leads to revolution and culminates in the establishment of the rational state.

\footnotetext{
${ }^{6}$ As will be discussed toward the end of next section, however, the theme of domestic reconciliation in Hegel's thought also makes it difficult that the Hegelian state limits warfare to a defensive purpose.

7 Hence Hegel's famous claim: 'in the oriental world, one is free; in the Greek and Roman world, some are free; and in the Germanic, all are free.' (Hegel 1975, p. 54). Yet, whether the rational state as immanent development of concrete freedom is identical with the European state model remains contested. See, for a critical analysis of Hegel's position on this issue, Tibebu (2011).
} 
Once the people have established the rational state, does this mean that they have to always conform to the authority of the constitution and meekly follow it? Hegel does not think so. In fact, he points out the need of gradual institutional reform even for the rational state. Of course, Hegel is fundamentally a thinker who values the crucial function of the constitution as the basic institutional structure of the state; the constitution, in his view, should condition every lawmaking activity of the modern state. But Hegel (1991, p. 336) also highlights that 'the constitution ... undergo[es] further development through the further evolution of the laws.' In his observation, the incremental modifications to the constitution slowly accumulate and at some point, the constitution would look like having gone through a considerable change (Hegel 1991, p. 337). The dysfunctional state appears when the constitution does not keep up with the progressive spirit of the people. In that case, the state puts itself in increasing discontent and becomes susceptible to revolution (Hegel 1995, pp. 269-271). Hegel (1964, p. 244) decries such inflexible states: 'How blind they are who may hope that institutions, constitutions, laws which no longer correspond to human manners, needs, and opinions, and from which the spirit has flown, can subsist any longer; or that forms in which intellect and feeling now take no interest are powerful enough to be any longer the bond of a nation.' Under this circumstance, Hegel would not disapprove of revolution. ${ }^{8}$

Thus, Hegel both rejects and accepts the idea of revolution. ${ }^{9}$ On the one hand, the theme of reconciliation is strong in the rational state. Unless a state remains immature (namely, completely lacking the moments of the rational constitution), Hegel would advise that our political activities be conditioned and mediated by the constitution. On the other hand, though, the reformist claim becomes stronger, eventually to the extent of revolution, if more and more rational individuals find their interests incompatible with the extant constitution and if the latter continues to fail to acknowledge their claims. Taking these two points together, it can be argued that although the theme of reform and even revolution never disappears in his thought, Hegel also thinks that the process of change is neither immediate nor dependent on individual (or collective) caprice.

This presentation of Hegel's thought as opposed to popular impatience with laws but open to gradual institutional reform is predicated upon the judgment that the modern state, in principle, is not the same as the ancient state-that is, not 'immature.' Needless to say, the extent to which the citizens of different states are devoted to their common space of politics and the ways in which the different governing bodies reflect their citizens' rational interests must be varied. Aside from such an empirical variation, though, most modern states at least aspire to take the form of the rational state in which individual interests are fully developed and recognized. Given his belief in this modern accomplishment, Hegel does not take revolution as something that has to be always praised and repeated for the initiatory dimension it creates. Instead, the act of revolution, for Hegel, involves making a

\footnotetext{
8 The more reformist (and less reconciliationist) language is found in Hegel's early writings. See, for more examples, Hegel (1936, p. 352, 1984, pp. 122-123, 1964, pp 243-245).

9 As Hutchings (2012, p. 138) suggests, the tension between these two points could be relieved if we do not approach Hegel normatively, that is, as if Hegel presented his idea of freedom as "a static universal."
} 
practical judgment, that of exploring a reasonable point of compromise between how our rational interests are acknowledged and how we cherish the common space as the constitution. ${ }^{10}$ Hegel trusts in the rationality embodied in the modern state, so he would first expect that individual claims to rights and welfare are mediated through the state's well-structured set of institutions. This emphasis on domestic reconciliation does not mean that Hegel is totally opposed to revolution. It only says that if the state takes a modern, rational form, the development of violent revolution would be slow to occur; and that insofar as the rational state accommodates gradual institutional reform, violent revolution would become less and less likely.

\section{Interstate conflict}

The preceding discussion leads to the question of whether the rationality embodied in the state could be also applied to international relations. If the rational principles are found in the modern state, can we appropriate them as the common standard to adjudicate interstate affairs? To put it in a different way, if most states adopt the same form of constitutional government, would it make the world easier to be regulated and peaceful? If it is Hegel's claim that individual interests and state interests are more and more reconciled, can we also take Hegel to argue that that would eventually create something like common world culture across state boundaries and the circumstance conducive to peace?

The argument, often dubbed 'the end of history,' offers the most affirmative response to these questions (Kojève 1980, pp. 158-162; Fukuyama 1992). It argues that the total rationalization of humankind would occur among Hegelian states, and this condition in turn would bring about a complete resemblance or homogenization of humanity across all states. Such a teleological worldview has many variants (Doyle 1986; Rawls 1999; Wendt 2003; Weiss 2009). But all these approaches underrate Hegel's emphasis on the exclusive nature of the rational state in its relations with other states. In so doing, they overlook the important feature of Hegel's notion of freedom that in order to take a concrete form, freedom must be situated and bounded. After all, those teleological arguments fail to capture a close relation of the internal aspect of the state to the external aspect of the state; that is, the state, for Hegel, does not pursue individuality for the sake of individuality, but the constitutive nature of the state (as the entity that actualizes individuals' freedom) mandates such an exclusive identity formation. Let me explain.

According to Hegel (1991, p. 359), the peaceful state within which domestic reconciliation occurs is 'that in which all branches of civic life subsist, while their collective and separate subsistence proceeds from the Idea of the whole.' This statement assumes two things: on the one hand, individual units should be able to

\footnotetext{
10 Geiger (2007, p. 6; pp. 94-139) argues that Hegel's statements about revolutionary war cannot fit with the existing ethical community, because war is in effect the complete collapse of the ethical sphere. In Hegel's view, however, revolution does not radically transform what is already in place or what has been found in the modern state-that is, the rational principles regarding how to actualize freedom in a concrete way. Besides, Hegel sees revolutionary war as more than showing the significance of the initiatory act for politics. Revolution, for Hegel, also serves as a reminder to reveal the importance of the constitutional state, without which the concrete way of actualizing freedom is not possible.
} 
identify themselves as members of the whole; on the other hand, the whole should be able to contain those units as its parts. ${ }^{11}$ Hegel (1991, p. 359) details this idea:

Internal sovereignty is this ideality in so far as the moments of the spirit and of its actuality, the state, have developed in their necessity and subsist as members of the state. But the spirit, which in its freedom is infinitely negative reference to itself, is just as essentially being-for-itself which has incorporated the subsistent differences into itself and is accordingly exclusive. In this determination, the state has individuality, which is [present] essentially as an individual and, in the sovereign, as an actual and immediate individual.

The state's 'individuality' discussed here refers to the status of the unity of diverse institutions (or 'moments of the spirit') that are developed in response to the rights and welfare of individuals. In other words, in pursuing individuality in its relations with other states, the state as a whole should make sure that its parts reach their full development and operate as different but connected members. This suggests that in Hegel's state model, different individual and collective entities are not those that await elimination but instead are contained as (reconciled) parts of the state. Accordingly, the cited passage confirms two aforementioned conditions of the Hegelian state: individuals should be able to identify themselves as members of the whole; yet, in order to accommodate those parts into itself, the state as a whole should be bounded. These features of Hegel's state help to see how the internal aspect of the state affects its external relations with other states. Having a delimited structure, or what Hegel prefers to call 'individuality,' the state follows the negative logic of the spirit in self-comprehension, and this in turn renders the state exclusive in its external relations with other states. Hence the contrasting logic: as the state actualizes internal integration (domestic reconciliation), its external representation takes an exclusive form (interstate conflict).

What this contrast implies for us is the difficulty in directly applying a shared ground established in the intradimensional politics into the interdimensional politics. According to Hegel, such a common ground is confined within the state, because individuals develop a particular way of reconciliation with the state, and the state as a whole-which contains those reconciled individuals-represents an exclusive identity in its external relations. That is, in interstate relations, the Hegelian state is seen to have a distinctive rational structure. In fact, this view on the rational state is consistent with the basic Hegelian narrative. Human beings develop moral obligations through interaction with communities. These communities in turn can hold different, or even conflicting, views on how general moral principles are to be interpreted and prioritized in local situations. Hegel thinks that at the highest level, the rational state plays a crucial role in achieving the good-the unity of two essential, conflicting qualities of freedom. Through the state, the citizens discover and develop distinctive ways of satisfying individual interests. As one commentator notes, Hegel considers 'the state as the largest effective ethical community [which] binds the individual in ways that smaller, partial communities should not and larger,

\footnotetext{
11 Erman (2013) captures this point when she argues that both the external interstate aspect and the internal intrastate aspect of statehood should be considered for the practice of state self-determination.
} 
more abstract communities cannot (Stillman 2009, p. 37).' In Hegel's belief, there is no adequate substitute for the sovereign state system if we desire to actualize concrete freedom. ${ }^{12}$

In order to understand Hegel's argument that the state needs to have an internally bounded and externally exclusive identity, let us pretend that the principles of sovereignty were nominal and the differences among states were almost nonexistent. ${ }^{13}$ In this situation, people travelled freely across state boundaries and imagined what they could do elsewhere that they could not do within their states. Because Hegel understands that the state exists only in the dispositions of individuals, those states in the purely cosmopolitan world would be too loose to function as an ethical community responsible for their citizens. Consequently, there would be no concrete way of actualizing freedom, except any number of indeterminate claims to abstract rights and welfare. Hegel here would remind us of the crucial role of the state for concrete freedom, arguing that for this cause of freedom, states are logically mandated to represent an exclusive identity.

What are the implications of this for the question of war? Earlier, we discussed that for Hegel, the citizens' patriotic disposition is embedded in the ordinary circumstances of life due to their habitual confidence in the state. As Shlomo Avineri (1996, p. 137) points out, such habituated patriotism should not be confused with the total militarization of entire civilian population. Rather, war in this situation appears as a possible manifestation derivative of the 'non-instrumental' relationship between the citizens and the state (Walt 1996, p. 173). In this regard, Hegel would reassure us that the state does not enforce citizens' sacrifice, but instead a duty of sacrifice emerges from, and constitutes, their reconciled relationship with the state.

But this account is certainly not enough to dismiss our concern about the Hegelian state. The Hegelian state system has two interconnected aspects of state sovereignty: for the internal actualization of freedom, the state is mandated to be exclusive in its relations with other states. By this contrasting relationship between domestic reconciliation and interstate conflict, it happens that the more the state is reconciled with its patriotic citizens, the higher the intensity of its interstate conflicts. Understood this way, war does not occur only among 'imperfect' states (either immature or dysfunctional). ${ }^{14}$ Those fully rational or 'perfect' states that achieve domestic reconciliation would have to wage war as well. Thus, if the occurrence of war is a standard according to which a state is judged to be imperfect,

\footnotetext{
12 Hegel (1991, p. 282) refers to the Holy Alliance, only to rebut it as 'purely relative and limited, like [the ideal of] perpetual peace.'

13 Greenhill (2008, p. 351) observes a similar problem that might occur if the state fails to have a bounded feature. In his view, this is likely to happen when constituent members 'seek recognition from different others,' the situation that would undermine the cohesiveness of existing collective identities. However, Greenhill overlooks that this is a problem that is more or less overcome in the Hegelian state. For Hegel, the 'living' state is not a compilation of different individual interests and needs (the kind which fits with Hegel's understanding of civil society). Instead, individuals are relatively reconciled with the state. Hence, the occurrence that a constituent member freely goes on to engage in the struggle for recognition with other collective or individual members may not be frequent enough to validate Greenhill's concern. We will revisit this point next section.

14 Hence, Vincent (1983, p. 203) is inaccurate to argue that 'war [for Hegel] is an indication of the imperfection of states.'
} 
the Hegelian state model suggests that once that state is perfect in domestic politics, it is imperfect in interstate relations.

Furthermore, the contrast between domestic reconciliation and interstate conflict complicates our (liberal) expectation that ' $[\mathrm{t}] \mathrm{he}$ purpose of war, for Hegel, is to defend freedom and to preserve the ethical life which makes it real for members of a particular political community (Gordon 2000, p. 321). ${ }^{, 15}$ Indeed, defensive war alone underestimates the destructive potential that derives from the intensifying confrontation between those states that have gained more and more individuality. The point is that such an external manifestation of states is not likely to create the situation conducive to war fought for defensive purposes. Hegel (1991, p. 369) is well aware of this problem when he observes:

But which of these [interstate] injuries should be regarded as a specific breach of treaties or as an injury to the recognition and honor of the state remains inherently indeterminable; for a state may associate its infinity and honor with any one of its individual interests, and it will be all the more inclined to take offense if it possesses a strong individuality which is encouraged, as a result of a long period of internal peace, to seek and create an occasion for action abroad. $^{16}$

The passage is clear about how the Hegelian state is enmeshed in interstate war. If the domestic reconciliation helps to accumulate a longer period of internal peace, it also takes the effect of pressuring the state to be more confrontational with other states by attaining a stronger individuality. Given this high intensity of conflict, it would not be surprising if the state becomes so sensitive to its recognition and honor that it initiates war. In addition, the national honor and the status of recognition cannot be considered rational factors-meaning that they would be much more difficult to institutionalize and control (e.g. Lindemann 2010). As Verene (1996, p. 152) points out, Hegel understands that 'peace [rarely] depends upon the institution of a set of principles for the actions of nations.' By observing those irrational aspects as manifested in interstate relations, Hegel remains skeptical about the claim that international affairs can be regulated by the common rational principles. Rather, interstate affairs among Hegelian states is much more conflictdriven, and more vulnerable to violence, than some liberal commentators argue. This is so, paradoxically, when those states seek to preserve the ethical life which makes freedom real for the citizens within their national boundaries.

\section{The scope of reconciliation}

At the outset of this paper, I identified two ways of appropriating Hegel's 'struggle for recognition.' One is the interpretation of Hegel that resonates with cosmopolitan theories of social movement and world culture. This approach focuses on Hegel's

\footnotetext{
15 See also Avineri (1996, pp. 137-139) and Rawls (2000, pp. 359-360).

16 Similarly, Hegel (1991, p. 362) argues that 'even if a number of states join together as a family, this league, in its individuality, must generate opposition and create an enemy.'
} 
idea of the master-and-slave narrative of recognition and uses it to raise the relevance of attending to the recognition and non-recognition status of local actors in conflict. From our discussion on Hegel, however, it is clear that such an interpretation underrates Hegel's persistent concern about the crucial role of mediation and the importance of the state for this purpose. Hegel believes that rationality is embodied in the rational state; in his view, maintaining and cultivating this modern asset is as important as identifying unacknowledged voices in society. He considers the state as the condition that enables the good (the unity of abstract rights and particular claims of welfare) to be actualized and thus finds it crucial for concrete freedom. To cosmopolitan theorists of global social movement, then, Hegel would ask whether and how concrete freedom can be effectively realized in other system than the state.

The other misunderstanding is to maintain that there is a strong reconciliatory dimension for interstate relations in Hegel's thought. Since I already discussed the difficulty to match a teleological worldview with Hegel's case of interstate war, in the following I focus on a recent variant of that, IR theorist Alexander Wendt's extensive analysis of the necessity of a world state (Wendt 2003). Unlike the aforementioned theories of global social movement, Wendt attends to Hegel's emphasis on state structure and its role of mediation. For example, Wendt (2005, p. 597) argues that structure contributes to 'agency's fullest expression,' rather than operating as 'always a limit on agency.' In his usage, however, structure connotes both the state in relation to individuals and the world state in connection with states. Wendt thus claims that the Hegelian struggle for recognition operates at interstate relations in the same way as at interpersonal interactions. That is, if individuals are reconciled with the constitutional state, so are states with the world state. What makes this possible, in Wendt's view, is that the state has independent personhood (Wendt 1999, pp. 193-245, 2004). Therefore, as in the case of human persons striving for recognition in Hegel's narrative, the state engages in struggles for recognition, which would eventually lead to the establishment of a world state.

Wendt's 'structuralist' presentation of IR social constructivism has generated numerous responses (e.g. Copeland 2000; Shannon 2005; Greenhill 2008; Wight 2004). Some critics even raise the concern that Wendtian structural determinism has the effect of obscuring the contingency of political action and denuding human agency (Scheuerman 2011, p. 146; Jackson 2004, p. 285; Franke and Roos 2010, pp. 1060-1063). But from the Hegelian perspective proposed in this article, Wendt should be credited at least for exploring the structural dimension of the state that is not reducible to its constituents. Not all activities of the state can be explained with reference to individuals and groups within the state. Hegel too thinks that the state is more than the compilation of individual interests. Individuals in Hegel's state model are those who are relatively reconciled with the state, though this understanding does not deny gradual institutional reforms. In Hegel's view, then, it is less persuasive to claim that individuals are the sole actors possessing active causal powers. Individuals do act and make changes in Hegel's state system, but the nature of their action is not driven by individuated socioeconomic interests or 
personal honors. ${ }^{17}$ Instead, reconciliation affects political action-that is, action appears as a mediated form in the context of the state that reflects the idea of the whole.

But the fact that individuals are reconciled with the state also highlights Wendt's misconstrual of Hegel's thought. True, Hegel describes the state as having individuality. This might invoke Wendt's claim that the state has actual personhood including some essential human qualities such as intentionality and consciousness. For Hegel, however, the state has individuality not because individuality is good for its own sake, but because in order to accommodate reconciled individual parts into itself, the state as a whole has to be bounded and exclusive. Instead of forcing an arbitrary agenda into its constituents, the state that Hegel advocates serves to actualize their freedom, so that each of them reaches distinctive development but operates as reconciled members in the state. The Hegelian state, at least in principle, is never discharged from this task of achieving concrete freedom. For Hegel, if reconciled individuals constitute the state, the state is also informed of the responsibility to achieve and sustain concrete freedom and domestic reconciliation. In terms of the causal power to explain the public world, then, neither the state having independent personhood nor the citizen pursuing an individuated socioeconomic interest is enough. Both reconciled individuals and responsible states should be taken into consideration.

If the state does not have the independent personhood that Wendt describes, it is difficult to accept his claim that states struggle for recognition and establish a world state. Hegel (1991, p. 368) makes it clear that states, unlike individuals in civil society, 'are primarily wholes which can satisfy their own needs internally.' That is, although the state holds some independent character irreducible to individual members, its activity is inclined toward meeting the demands of concrete freedom and domestic reconciliation. This dual feature renders states totalities that are nonetheless dependent on their internal needs. Thus, '[their] relationship ... is a relationship of independent units which make mutual stipulations but at the same time stand above these stipulations (Hegel 1991, p. 366).' The Hegelian state has a fundamental concern about domestic reconciliation, and this need makes the reflexive effect that the state as a whole that contains reconciled constituent members should be exclusive in its external relations with other states. As a result, the common concern about freedom among Hegelian states is bounded within each state and thus remains a thin version of communication across state boundaries (Hegel 1991, p. 368). Moreover, from Hegel's state model it is revealed that the more the state achieves domestic reconciliation for concrete freedom, the stronger its individuality. This creates the environment under which states are more and more sensitive to their recognition status and honor. So, the contrasting relationship between domestic reconciliation and interstate conflict found in Hegel's thought

\footnotetext{
17 In their critique of Wendt's idea of state personhood, Franke and Roos (2010, pp. 1071-1072; p. 1076) argue that whereas the social world is composed of 'Me-self' (structural potentials) and 'I-self' (disruptive actors), it is 'I-self' or its contingent character that causes change. But Hegel would question if those disruptive actors always constitute the modern state, and if the state can be easily disposed of for individuals' subjective caprice.
} 
makes Wendt's depiction of a gradually stabilizing world much more difficult to accept.

\section{Conclusion}

Hegel's concept of the struggles for recognition has received much attention in recent scholarship on international politics. Its increasing popularity might be attributed to his equal interest in conflict and reconciliation. But in terms of how to situate these two themes in Hegel's thought, scholars have provided varied responses. The main purpose of this paper was to articulate how for Hegel, conflict and reconciliation are varied according to domestic and interstate levels of politics. For this, two points were made. The first was that Hegel is a theorist who opposes the mere reduction of citizens to docile subjects but nonetheless argues for their commitment to the constitutional state. Owing to his trust in the rationality embodied in the modern state, Hegel advocates gradual institutional reforms, not recurrent revolution. The second claim was that in order to achieve and maintain concrete freedom and domestic reconciliation, Hegel observes that the state has to be internally bounded and externally exclusive. The contrasting relationship between domestic reconciliation and interstate conflict is crucial for understanding Hegel's views on the state, war, and international relations.

This interpretation of Hegel's political thought implies two things. One implication is to direct our attention to the fundamental purpose of the modern state. Many inquiries about the state and interstate relations tend to focus on the condition of sheer survival. Perhaps, the image of the state's wrongdoings-such as forced displacement, genocide, or imperialistic/hegemonic war-is so strong that we are often oblivious to the actual idea of the rational state. But Hegel makes it clear that the significance of the state lies in the actualization of concrete freedom. In so doing, he questions whether concrete freedom can be effectively achieved in any alternative system to the state. Secondly, this reading urges us to examine if all conflicts at the interstate level ought to be considered as a negative obstacle to overcome. To be sure, it is understandable that contemporary theorists tend to reject interstate conflict altogether. Dehumanized modern warfare, with its WMD threats and drone strikes, presents a greater challenge to humanity. But we are also reminded of Hegel's assertion that the rational state is necessary for mediating different individual interests and achieving concrete freedom. This claim in turn means that citizens need to cherish and cultivate the constitution and public institutions. Such a public commitment does not imply a docile subjection to the governing body, but rather a commitment to existing values and a willingness to sacrifice for their protection. The sort of interstate conflict as rooted in such patriotism is honor-driven, and the idea that rational states vie for honor and excellence needs a language different from that of interest and fear. ${ }^{18}$ In short, we

\footnotetext{
18 For the fledging research on the honor-driven dimension of interstate conflict, see Lebow (2006) and Tsygankov (2012, pp. 13-27).
} 
should explore and examine the honor-driven dimension of interstate conflict rather than dismissing it entirely in the first place.

But this also means that we should be mindful of a problem Hegel's state model creates. If an honor-driven confrontation among Hegelian states is intensified (as Hegel himself predicts), there might be a danger to slip into the process of (re-) constructing the state as a thicker community of authenticity by appealing to some pseudo-natural criteria. ${ }^{19}$ The question is then whether Hegel's state model has any effective way of resisting such a temptation. This also leads us to raise the question: How do we cherish our common space for freedom and vie for honor and excellence, while not falling into the dangers of treating others as permanent enemies and engaging in a war of annihilation? How do we achieve concrete freedom and domestic reconciliation, while simultaneously relieving interstate conflict?

In revealing this kind of complexity laid in freedom, the state, and war, Hegel's challenge to world peace has a special meaning. And this insight has not been sufficiently reflected in the recent cosmopolitan theories that appropriate Hegel's thought.

Acknowledgements An earlier version of this paper was presented at the 2015 meeting of the International Studies Association, New Orleans, LA. I thank the participants in the panel for their critical comments and questions. I am also grateful to Dana Villa, Ernesto Verdeja, Catia Confortini, Cameron O'Bannon, and Vince Bagnulo for their helpful discussions on this project.

\section{References}

Adorno, T. 1973. Negative dialectics. New York: Seabury Press.

Avineri, S. 1996. The problem of war in Hegel's thought. In The Hegel myths and legends, ed. J. Stewart, 131-141. Evanston, IL: Northwestern University Press.

Bartelson, J. 2013. Three concepts of recognition. International Theory 5 (1): 107-129.

Brook, T. 2012a. Hegel's political philosophy: A systematic reading of the philosophy of right, 2nd ed. Edinburgh: Edinburgh University Press.

Brook, T. 2012b. Between statism and cosmopolitanism: Hegel and the possibility of global justice. In Hegel and global justice, ed. A. Buchwalter, 65-83. New York: Springer.

Brown, C. 2002. Sovereignty, rights and justice: International political theory today. Cambridge: Polity. Cassirer, E. 1946. The myth of the state. New Haven, CT: Yale University Press.

Copeland, D. 2000. The constructivist challenge to structural realism. International Security 25 (2): 187-212.

Doyle, M.W. 1986. Liberalism and world politics. American Political Science Review 80 (4): 1151-1169.

Erman, E. 2013. The recognitive practices of declaring and constituting statehood. International Theory 5 (1): $129-150$.

Franco, P. 1999. Hegel's philosophy of freedom. New Haven, CT: Yale University Press.

Franke, U., and U. Roos. 2010. Actor, structure, process: Transcending the state personhood debate by means of a pragmatist ontological model for international relations theory. Review of International Studies 36 (4): 1057-1077.

Fukuyama, F. 1992. The end of history and the last man. New York: Free Press.

\footnotetext{
${ }^{19}$ Hegel is critical of Romanticism and tries to distinguish the national state from the constitutional state, the Rechtsstaat that is devoted to the rule of law. But as Villa (2008, pp. 252-254) notes, Hegel remains attached to the Romantic ideas, in that he objects to alienation and appeals to reconciliation between humanity and an increasingly objectified nature. Here, the concern is that the strong theme of reconciliation embedded in the Hegelian state may have the effect of treating alienated individuals as a thing to overcome in the long run, rather than as the critical entity that prevents any attempt to connect political communities with rigid claims of naturalness on which some type of Gemeinschaft is grounded.
} 
Galtung, J. 1969. Violence, peace, and peace research. Journal of Peace Research 6 (3): 167-191.

Geiger, I. 2007. The founding act of modern ethical life: Hegel's critique of Kant's moral and political philosophy. Stanford, CA: Stanford University Press.

Geuss, R. 2010. Politics and the imagination. Princeton, NJ: Princeton University Press.

Gordon, R. 2000. Modernity, freedom, and the state: Hegel's concept of patriotism. The Review of Politics 62 (2): 295-325.

Greenhill, B. 2008. Recognition and collective identity formation in international politics. European Journal of International Relations 14 (2): 343-368.

Hegel, G.W.F. 1936. Aus Jenenser Vorlesungen. In Dokumente zu Hegels entwicklung, ed. J. Hoffmeister, 335-352. Stuttgart-Bad Canstatt: Friedrich Frommann Verlag.

Hegel, G.W.F. 1964. On the recent domestic affairs in Wuerttemberg. In Hegel's political writings, ed. T.M. Knox, 243-245. Oxford: Clarendon Press.

Hegel, G.W.F. 1975. Lecture on the philosophy of world history. Cambridge: Cambridge University Press.

Hegel, G.W.F. 1977. Phenomenology of spirit. Oxford: Oxford University Press.

Hegel, G.W.F. 1984. Hegel: the letters. Bloomington, IN: Indiana University Press.

Hegel, G.W.F. 1991. Elements of the philosophy of right. Cambridge: Cambridge University Press.

Hegel, G.W.F. 1995. Lectures on natural right and political science. Berkeley, CA: University of California Press.

Honneth, A. 1996. The struggle for recognition: The moral grammar of social conflicts. Cambridge, MA: The MIT Press.

Hutchings, K. 2012. Hard work: Hegel and the meaning of the state in his philosophy of right. In Hegel's philosophy of right: Essays on ethics, politics, and law, ed. T. Brooks, 124-142. Malden, MA: Blackwell Publishing.

Jackson, P.T. 2004. Hegel's house, or 'people are states too'. Review of International Studies 30 (2): 281-287.

Jaeger, H. 2002. Hegel's reluctant realism and the transnationalization of civil society. Review of International Studies 28 (3): 497-517.

Kaldor, M. 2013. Reconstructing global security for the twenty-first century. In The quest for security: Protection without protectionism and the challenge of global governance, ed. J.E. Stiglitz, and M. Kaldor, 117-142. New York: Columbia University Press.

Kojève, A. 1980. Introduction to the reading of Hegel: Lectures on the phenomenology of spirit. Ithaca, NY: Cornell University Press.

Lebow, R.N. 2006. Fear, interest, and honor: Outlines of a theory of international relations. International Affairs 82 (3): 431-448.

Lebow, R.N. 2008. Identity and international relations. International Relations 22 (4): 473-492.

Lederach, J.P. 1998. Building peace: Sustainable reconciliation in divided societies. Washington, DC: United States Institute of Peace.

Lederach, J.P. 2003. The little book of conflict transformation. New York: Good Books.

Lindemann, T. 2010. Causes of war: The struggle for recognition. Colchester: ECPR Press.

Lindemann, T., and E. Ringmar (eds.). 2012. The international politics of recognition. Boulder, CO: Paradigm Publishers.

Mouffe, C. 1993. The return of the political. London: Verso.

Pippin, R.B. 2008. Hegel's practical philosophy. Cambridge: Cambridge University Press.

Popper, K. 1996. The open society and its enemies. London: Routledge.

Richmond, O. 2011. A post-liberal peace. London: Routledge.

Rawls, J. 1999. The law of peoples. Cambridge, MA: Harvard University Press.

Rawls, J. 2000. Lectures on the history of moral philosophy. Cambridge, MA: Harvard University Press.

Scheuerman, W. 2011. The realist case for global reform. Cambridge: Polity.

Shannon, V. 2005. Wendt's violation of the constructivist project: Agency and why a world state is not inevitable. European Journal of International Relations 11 (4): 581-587.

Shelton, M. 2000. The morality of peace: Kant and Hegel on the grounds for ethical ideals. The Review of Metaphysics 54 (2): 379-408.

Smith, J. 2007. Social movements for global democracy. Baltimore, MD: Johns Hopkins University Press.

Smith, S. 1983. Hegel's views on war, the state, and international relations. American Political Science Review 77 (3): 624-632. 
Stillman, P. 2009. Hegel as a colonial, anticolonial, and postcolonial thinker. In Europe and its boundaries: Words and worlds, within and beyond, ed. A. Davison, and H. Muppidi, 25-47. Lanham, MD: Lexington Books.

Taylor, C. 1994. The politics of recognition. In Multiculturalism: Examining the politics of recognition, ed. A. Gutmann, 25-73. Princeton, NJ: Princeton University Press.

Tibebu, T. 2011. Hegel and the third world: The making of eurocentrism in world history. Syracuse, NY: Syracuse University Press.

Tsygankov, A.P. 2012. Russia and the west from Alexander to Putin: Honor in international relations. Cambridge: Cambridge University Press.

Verene, D.P. 1996. Hegel's account of war. In The Hegel myths and legends, ed. J. Stewart, 142-153. Evanston, IL: Northwestern University Press.

Villa, D. 2008. Public freedom. Princeton, NJ: Princeton University Press.

Vincent, A. 1983. The Hegelian state and international politics. Review of International Studies 9 (3): 191-205.

Wallace, R.M. 1999. How Hegel reconciles private freedom with citizenship. Journal of Political Philosophy 7 (4): 419-433.

Walt, S. 1996. Hegel on war: Another look. In The Hegel myths and legends, ed. J. Stewart, 167-180. Evanston, IL: Northwestern University Press.

Weigert, K.M. 2008. Structural violence. In Encyclopedia of violence, peace, and conflict, ed. L.R. Kurtz, 2004-2011. Waltham, MA: Academic Press.

Weiss, T.G. 2009. What happened to the idea of world government. International Studies Quarterly 53 (2): 253-271.

Wendt, A. 2005. Agency, teleology and the world state: A reply to Shannon. European Journal of International Relations 11 (4): 589-598.

Wendt, A. 2004. The state as person in international theory. Review of International Studies 30 (2): 289-316.

Wendt, A. 2003. Why a world state is inevitable. European Journal of International Relations 9 (4): 491-542.

Wendt, A. 1999. Social theory of international politics. Cambridge: Cambridge University Press.

Wight, C. 2004. State agency: Social action without human activity? Review of International Studies 30 (2): 269-280.

Williams, B. 2005. Realism and moralism in political theory. In In the beginning was the deed: Realism and moralism in political argument, ed. G. Hawthorn, 1-17. Princeton, NJ: Princeton University Press.

Wood, A. 1990. Hegel's ethical thought. Cambridge: Cambridge University Press. 